\title{
SOME MINERAL DEFICIENCIES AND EXCESSES IN CATTLE AND SHEEP IN BRITAIN
}

By RUTH ALLCROFT, Senior Research Officer,

Veterinary Laboratory, Ministry of Agriculture,

Fisheries and Food, Weybridge, Surrey, England.

Although the production of good pasture is a starting point, one end point is a prime, healthy animal.

At Weybridge, we have many animal health problems associated with the grazing of apparently good pastures, and it is some of these problems that I propose to discuss this afternoon: Because some of these disorders are not associated with a deficiency of minerals in the herbage itself, it may be misleading to refer to them merely as "trace element" or "mineral deficiency" diseases, which usually implies a deficient intake of some essential dietary constituent rather than a dysfunction of the mineral metabolism of the animal.

\section{Magnesium}

Hypomagnesaemic tetany, commonly referred to as "grass tetany," "grass staggers," or "lactation tetany," is usually included in the so-called "metabolic disorders" such as milk fever and ketosis, but it is discussed here, not only because it is a disease of considerable economic importance in Britain and other European countries as well as in New Zealand, but also because there is growing evidence that some forms of the disorder are related to dietary factors (Blaxter and McGill, 1956).

Most investigators agree that the disorder is not caused by deficiency of magnesium in the classical sense, since pastures on which it occurs show a magnesium content as high and sometimes higher than pastures on which it does not occur; even on soils which respond to magnesium fertilisers, -the incidence of hypomagnesaemic tetany appears to be no greater than on soils rich in magnesium. Nevertheless, there is a good deal of evidence which shows that an increase in the magnesium intake of cattle can prevent, or at least mitigate, the fall of serum magnesium levels (Allcroft, 
1953 ; Stewart, 1954 ; Blaxter and McGill, 1956). The use of oral supplements of magnesium oxide have proved to be very effective under certain conditions (Allcroft, 1954) and this has been widely confirmed by farming experience in Britain.

Swan and Jamieson (1956) have shown that a deficient food energy intake is one cause of hypomagnesaemia in lactating cows. Clinical cases of grass staggers were produced by underfeeding alone, but occurred more readily when thryroprotein dosing was superimposed on the underfeeding. Norwegian workers have also demonstrated that hypomagnesaemia could be induced in stall-fed lactating cows on a low magnesium/low energy diet (Breirem, Ender, Halse, and Slagsvold, 1949). Some trials at Weybridge, however, showed that even lower magnesium intakes did not produce significant hypo-magnesaemia in 2-yearold stall-fed heifers whether on high or low energy diets, but these animals were not subjected to the additional strain of lactation as were the Norwegian cattle.

The evidence, so far, indicates that there are two main types of the disease in the bovine; one is a rapidly developing type most commonly associated with a flush growth of grass in spring and autumn, while the other is a slowly developing or seasonal type (Green, 1948). The first is most prevalent in dairy animals, and although most common during spring and autumn and least common during the summer, the condition can occur at any time in cattle in Britain, either at grass or on stall feeding. It is not confined to any particular age, sex, or breed, but the incidence is low in Jersey cattle and is practically unknown in this breed in their native island. This seems to be an interesting contrast to the incidence of the disorder in Jersey cattle in New Zealand.

The slowly developing or seasonal type is most prevalent in beef cattle, dry cows, and young stock, and occurs more frequently during the winter than during the season of rapid growth of grass. A marked association has been reported (Allcroft, 1947) between low serum magnesium values in out-wintered beef cattle and wet, cold, windy weather. In beef cows the highest incidence usually occurs a few weeks after winter calving when pasture growth is very slow and consequently when the plane of nutrition is generally poor. It is often at this time, especially, that a sudden, wet, cold spell of weather may precipitate clinical cases ; that is, at a time when the animal is subjected 
to heavy stresses, such as lactation, low plane of nutrition and high loss of body heat.

Even though there appears to be no association with soil type, and no correlation between the magnesium content of the soil or pasture and the severity of the disease, the condition does appear to be more prevalent on some farms than on others. The increased incidence is often associated with improvement of grassland and/or the adoption of an intensive system of rotational grazing where'application of artificial fertilisers is heavy.

Collaborative work at Shinfield and Weybridge (Bartlett et al., 1954) indicated a greater incidence of the disease on a cocksfoot and clover sward which had been given a heavy dressing of sulphate of ammonia than on a similar sward which had no nitrogenous dressing that season. When a heavy application of a commercial grade of magnesium oxide was given before the sulphate of ammonia, the magnesium content of the pasture was doubled and little hypomagnenaemia and no clinical cases of tetany occurred. The occurrence or absence of hypomagnesaemia in the cows grazing the various experimental plots could not, however, be correlated with pasture magnesium values and the possibility must be considered that the beneficial effect of the magnesium oxide dressing may have been due to an alteration in soil conditions resulting in the absence of "tetany-producing" factors in the pasture, rather than to an increased magnesium content per se of the sward.

The application of magnesium compounds to experimental plots was studied in New Zealand by Cunningham (1936), who used dressings of both magnesium sulphate and dolomite. Although these dressings appreciably increased the magnesium content of the sward, it was not considered that the intake of magnesium by the grazing animal could be increased economically by these methods. More recent investigations by Scottish workers (Stewart, 1953 and Stewart and Reith, 1956) have also shown increases in the magnesium content of pastures dressed with magnesium limestone, and this effect was correlated with the maintenance of normal serum magnesium levels of cattle grazing the treated pastures. Work is now being carried out at Weybridge to study the value of magnesian limestone dressings under controlled conditions and to compare it with the use of magnesium oxide, which is too expensive for large scale application. The results so far obtained (Parr and Allcroft, 1956) confirm that 
the magnesium content of pasture can be raised by magnesium manures and that this has a beneficial effect on serum magnesium levels in cattle. They also indicate that the uptake of magnesium can be influenced by other manurial treatments, particularly those involving the use of calcium. The use of magnesian limestone on soils which have a definite lime require-' ment seems justified as a step toward the control of hypomagnesaemia, but it is unlikely that it would be of value on soils with an already adequate lime status. Magnesium oxide or other magnesium rich compounds are likely to give better results on such soils, but much work remains to be done on this aspect of prevention as well as on the metabolism of magnesium in the animal itself.

The incidence of hypomagnesaemic tetany in the calf appears to have increased during the last few years. Blaxter and Sharman (1955) have suggested that the disease is due to a simple dietary deficiency of magnesium. associated with the liberal feeding of whole milk. Evidence from field reports collected at Weybridge indicate that although it is frequently associated with a high milk intake, it can occur in calves under all conditions of feeding and management.

Although this disease is much more prevalent in cattle than in sheep, Weybridge records show that clinical symptoms associated with hypomagnesaemia are fairly common in both hill and lowland flocks. The incidence of clinical cases is highest during the 4-week period after lambing, the peak usually occurring at 10-14 days after parturition. In some lowland flocks the disorder has been associated with improvement of pastures, with the use of simple seeds mixtures, and with increased use of artificial fertilisers; nevertheless, the incidence in hill flocks on poor grazing is not negligible in some seasons.

\section{Copper and Molybdenum}

So much has already been reported on the metabolic inter-relationship of copper and molybdenum in ruminants, that it will be more convenient to deal briefly with related aspects of copper deficiency and molybdenum excess in cattle and sheep in Britain than to discuss them separately.

The peculiarity of copper deficiency in Britain is that the condition occurs on pastures normal or even high in copper content and is therefore an "induced" or "conditioned" deficiency. Low copper values in pasture grasses have, so far, been found only for short 
periods during spring growth in a few isolated areas, chiefly in East Anglia, and also in a few cereal and other crops.

Historically, the associated clinical disorders were observed in Britain, first in sheep, and then in cattle, but economically, the disorder is now of greater importance in cattle.

The chief manifestation of copper deficiency in sheep in Britain is the occurrence of "swayback" or neonatal ataxia in lambs, which is pathologically similar to "enzootic ataxia" which occurs in Australia and New Zealand.. Apart from the well-known symptoms and pathological lesions which characterise this disorder in lambs, no other abnormality has been associated with a low copper status of sheep in Britain. Although there is ample proof that administration of copper to the ewe during the gestation period will prevent the occurrence of swayback in lambs and although low blood and liver copper values have always been found in affected lambs and their mothers, many liver samples have shown equally low copper values without any evidence of demyelination or of clinical manifestations of swayback in the flock. It would seem possible, therefore, that a low copper status alone does not necessarily produce the lesions of swayback and that another factor may also be concerned which

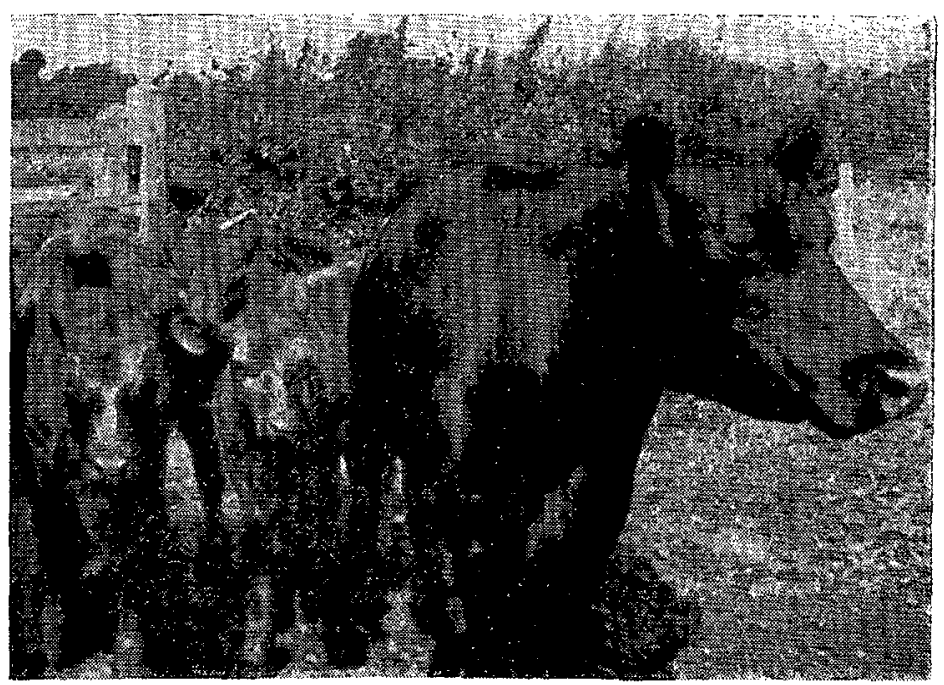

Copper deficiency in 'Aberdeen Angus cattle. Calves show severe symptoms of copper deficiency while the mother appears clinically normal. 


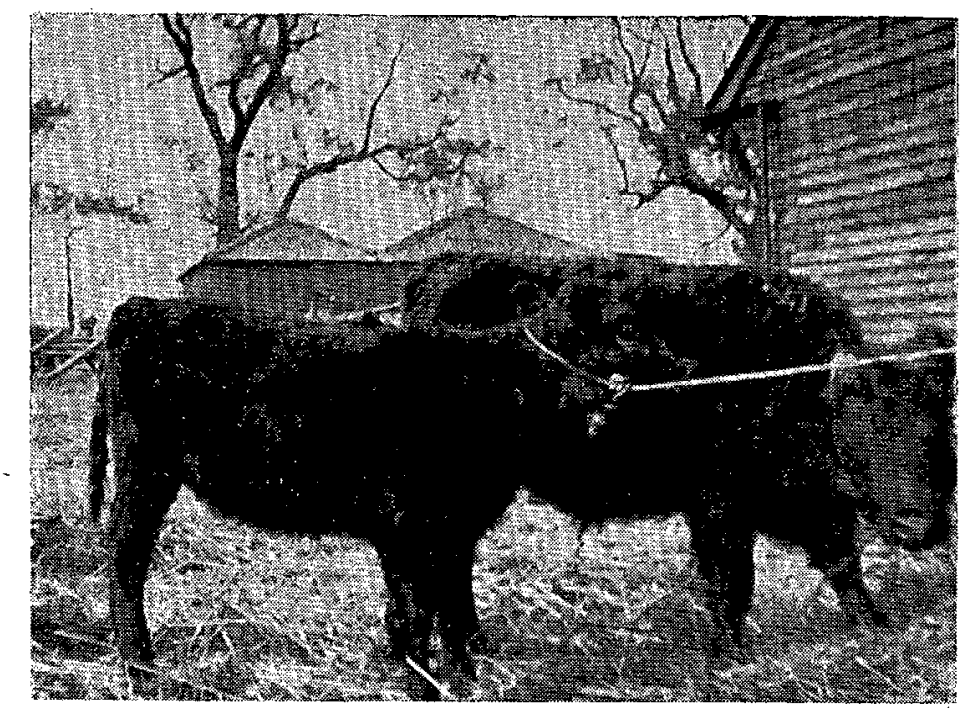

Effect of intravenous administration of $50 \mathrm{mg}$ of copper to calf on right. Calf on left, which is same age, is untreated;

operates to produce -demyelination of the nervous system of the lamb only when the copper status of both ewe and lamb is low.

Copper deficiency in cattle is reflected by a wide variety of non-specific clinical manifestations, "the chief of which is progressive loss of condition. Diarrhoea is not always present; in some cases it is severe while in others it is absent. Concurrent anaemia is uncommon. Adult as well as young stock are affected; but frequently, especially in beef herds, the calves are severely affected, while their mothers appear clinically normal, even though the copper status of both may be verylow. Administration of small quantities of copper usually gives a spectacular response in increase of growth in these cases.

: . Hypocuprosis in cattle has' been observed in many different areas widespread throughout the country. Our evidence does not indicate that it is confined to any particular soil type, and although it is usually found in varying degrees of severity in cattle grazing peaty areas, it is by no means confined to these.

Its occurrence on pastures of normal or even high copper content obviously suggests the presence of 
other constituents in the herbage which interfere with the utilisation of copper in the animal.

The harmful effects to ruminants of a relatively high molybdenum/copper ratio are well known and have been demonstrated in several parts of the world since Ferguson, Lewis and Watson (1943) showed that the scouring and unthriftiness that occur in cattle on the "teart" pastures in Somerset were directly related to the water-soluble molybdenum in the herbage. Cunningham (1950) has shown that a relatively. high intake of molybdenum can reduce liver copper storage in cattle and sheep, can reduce growth rate in calves, and produce a clinical picture of scouring and unthriftiness similar to natural cases of "peat scours." Our experimental observations agree with his findings as far as the bovine is concerned and in some areas, espe- cially on peat soils, the relative amounts of copper and molybdenum in the pastures fall, within" the range which he has shown to be harmful for cattle (1950 and 1955). In many other areas, however, this does not appear to be the explanation, since copper deficiency symptoms are by no means always associated with adverse copper/molybdenum levels and have been observed on pastures with values similar to those found for many "healthy" pastures. Also, there appears to be no relationship between the copper and molybdenum content of pastures and the incidence of swayback.

Dick (1953-54) has demonstrated that the inorganic sulphate content of the diet can influence the effect of molybdenum on liver copper storage in sheep, but a difference in the sulphate content of healthy and affected pastures does not appear to be a significant factor in the occurrence of hypocuprosis.

Table I shows some mean values of copper, molybdenum and inorganic sulphate contents of pastures on which hypocuprosis in cattle and swayback in lambs does and does not occur (Allcroft and Lewis -1956).

These data, then, suggest that there are factors other than (1) a dietary deficiency of copper; (2) an excess of molybdenum relative to copper; or (3) a difference in the sulphate content of the pastures which can cause copper deficiency in cattle and sheep. Nor do these factors appear to be the only ones which influence accumulation of copper in sheep, since deaths due to chronic copper poisoning have occurred in stalled sheep at Weybridge on diets supplying approximately normal concentrations of these three constituents (12 p.p.m. $\mathrm{Cu}, 1$ p.p.m. Mo, and 0.7 g. per cent inorganic sulphate). It would seem, therefore, that there are 
TABLE I.-Copper, molybdenum, and inorganic sulphate content, of pastures on which copper, deficiency in cattle and sheep has and has not occurred.

\begin{tabular}{|c|c|c|c|c|c|c|c|}
\hline \multirow[b]{2}{*}{ Description } & \multirow{2}{*}{$\begin{array}{l}\text { No. of } \\
\text { Samples }\end{array}$} & \multirow[b]{2}{*}{ Mean } & \multirow{2}{*}{$\begin{array}{l}\text { Copper } \\
\text { p.p.m./D.h } \\
\text { Range }\end{array}$} & \multicolumn{2}{|c|}{$\begin{array}{ll}\text { I } & \text { Molybdenum }\end{array}$} & \multicolumn{2}{|c|}{$\begin{array}{l}\text { Inorganic Sulpliate } \\
\text { g. } \% / \mathrm{D} \text {.W. }\end{array}$} \\
\hline & & & & Mean & Range & Mean & $\begin{array}{l}\text { Range } \\
\text { Rang. }\end{array}$ \\
\hline $\begin{array}{l}\text { Cattle Pastures } \\
\text { 1. No copper deficiency } \\
\text { (a) Non-industrial areas } \\
\text { (b) Industrial areas }\end{array}$ & $\begin{array}{l}20 \\
11\end{array}$ & $\begin{array}{l}12 \\
22\end{array}$ & $\begin{array}{l}6.2-21 \\
15-35\end{array}$ & $\begin{array}{l}1.1 \\
3.5\end{array}$ & $\begin{array}{r}0.32-2.1 \\
2.0-7.5\end{array}$ & $\begin{array}{l}0.67 \\
0.83\end{array}$ & $\begin{array}{l}0.49-0.90 \\
0.40-1.3\end{array}$ \\
\hline $\begin{array}{l}\text { 2. Copper denciency areas } \\
\text { (b) Industrial areas as. } \\
\text { (b) Industral }\end{array}$ & $\begin{array}{r}5 \\
13\end{array}$ & $\begin{array}{l}15 \\
24\end{array}$ & $\begin{array}{l}13-18 \\
13-37\end{array}$ & $\begin{array}{l}2.1 \\
7.0\end{array}$ & $\begin{array}{l}1.1-4.3 \\
1.5-15\end{array}$ & $\begin{array}{l}0.72 \\
0.58\end{array}$ & $\begin{array}{l}0.44-0.82 \\
0.24-1.10\end{array}$ \\
\hline $\begin{array}{l}\text { Sheep Pastures } \\
\text { 1. No swayback } \\
2 . \quad \text { S w a y b a c k }\end{array}$ & $\begin{array}{l}44 \\
15\end{array}$ & $\begin{array}{l}18 \\
14\end{array}$ & $\begin{array}{l}6.2-35 ' \\
8.4-20\end{array}$ & $\begin{array}{l}1.2 \\
1.6\end{array}$ & $\begin{array}{l}0.39-2.5 \\
0.46-3.6\end{array}$ & $\begin{array}{l}0.61 \\
0.68\end{array}$ & $\begin{array}{l}0.23-0.91 \\
0.45-0.95\end{array}$ \\
\hline
\end{tabular}


other factors, as yet unknown, which can profoundly influence copper metabolism in cattle and sheep.

\section{Cobalt}

Cobalt deficiency does not appear to be of such economic importance in Britain as it is in New Zealand and Australia. The disorder is less common in England than in Scotland where systematic mapping has been carried out and cobalt deficient areas were reported by Stewart, Mitchell, and Stewart (1946). Patterson (1946) has described cobalt deficiency in sheep on the granite and sandstone soils of Devon and Cornwall and later observations by Osborne, Featherstone and Herdan (1954) indicate that marginal and seasonal deficiencies of cobalt occur in Herefordshire and Worcestershire.

\section{Fluorine}

The problem of fluorosis in farm animals in Britain is not due to the high fluorine content of rock phosphate deposits, volcanic soils, or water supplies, but arises from the emission of fluorine containing gases and dusts from industrial plants. If the density of our industrial areas is considered in relation to the relatively small area of the whole country, it can be readily understood that a great deal of agricultural land must be adjacent to industrial works.

The chief sources of fluorine contamination of grassland and crops are: (1) steel and metal works when the method of production involves the use of large amounts of fluorspar as a flux ; (2) brickworks, where the source is usually the local clay, although coal is sometimes a contributory factor; (3) production of aluminium by the electrolytic reduction of alumina; (4) glass, enamel, and colour works where fluorine compounds are often added to facilitate melting and to give the finished products certain properties; (5) the calcining of iron-stone where the source is mainly the fluorine-rich ore itself; (6) potteries and other ceramic industries where the materials used in manufacture are high in fluorine; (7) collieries, power stations and other industries which consume large quantities of pulverised low-grade coal with a high fluorine content.

It is generally accepted that the fluorine content of most plants, with the exception of the roots, is not readily affected by the amount of fluorine in the soil. There seem to be a few exceptions to this, notably the tea plant. and the camellia, which appear to be fluorine collectors, but common fluorine values for 


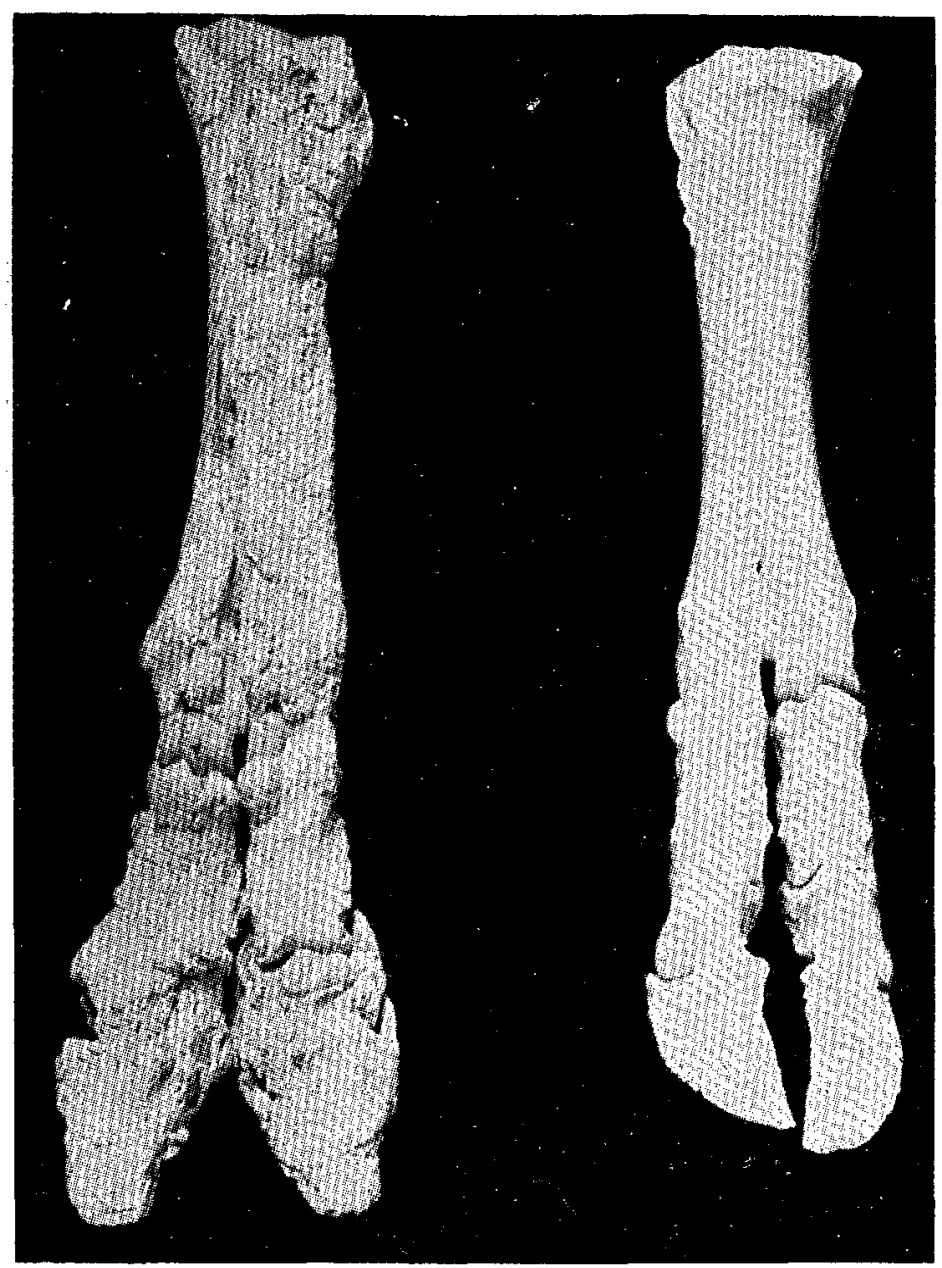

The chief chemical sign of fluorosis in severely affected cattle is lameness, which is frequently associated with marked skeletal abnormalities such as an increase in diameter of bones and well defined exostoses. Enlargement and gross exostoses in bovine limb bones (left) compared with normal bones (right).

uncontaminated animal foodstuffs lie between 1 and 10 p.p.m. on a dry matter basis. Excessively high values' up to 2000 p.p.m. have been reported (Green 1946) on herbage near sources of emission of fluorine compounds. Herbage and soil samples provide useful corroboration, but are not suitable alone for assessing 
degree and extent of contamination, since results will depend on climatic conditions around the time of sampling, on the direction of the prevailing winds, and on the topography of the surrounding terrain. It is difficult to suggest a minimum fluorine value for contaminated pastures at which clinical cases of fluorosis will occur, because of the variable factors first mentioned, and because the all-important factor is the length of time over which the foodstuff is consumed at , any particular level of contamination. And since development of clinical symptoms is slow, a pasture analysis only demonstrates that contamination is present; it 'cannot give a direct correlation of the degree of fluorosis in the animal.

Present evidence suggests that the order of susceptibility of farm animals to fluorosis is calves, dairy cows, other bovines, sheep, pigs, horses, and poultry, but this order may be revised when comparative tests on a known and comparable body weight intake have been carried out, The chief clinical symptom in severely affected cattle is lameness, and it is this which usually suggests the possibility of fluorosis and leads to a closer investigation of the herd. The lameness is frequently associated with marked skeletal abnormalities such as an increase in diameter of limb bones and well-defined exostoses. Dental lesions in the permanent teeth of cattle reared on affected farms are one of the best indications of the presence and degree of fluorosis. They include loss of lustre, pitting, staining in parts of the defective enamel, and excessive and irregular wear. Clinical diagnosis can be confirmed by determination of the fluorine content of urine and bone samples.

Although the total economic loss due to fluorosis is not great when considered in relation to that caused by the major transmissible diseases, it is a matter of serious concern in affected areas and methods of control are being studied both by industry and agriculture. Reduction of emission can be achieved to some extent in some industries by trapping and washing the dusts and gases, but in others the practical difficulties and the costs would be so great that it is unlikely that efficient devices could be installed. Some degree of agricultural control can be achieved by farming with the fluorine hazard in view, e.g., improvement of pasture management, limitation of grazing periods; keeping pigs and poultry instead of cattle and sheep, or using the land for production of crops only. The possibility of alleviating the effects of fluorosis in cattle 
by feeding certain mineral supplements is also being investigated by the Ministry on an experimental farm on which fluorosis occurs.

\section{lodine}

It has been thought that typical iodine deficiency in farm stock in Britain is rare, but thyroid hyperplasia in new-born calves occurs not infrequently and hypothyroidism in cattle and its possible relationship with reproductive disorders have been reported (Allcroft, Scarnell, and Hignett, 1954). There are reports too of congenital goitre in lambs. Jamieson and Harbour (1947) recorded its occurrence in lambs from ewes running on grassland, while Shand (1952) described an outbreak resulting from excessive feeding of kale to pregnant ewes. Subsequent investigation of the goitrogenic factor in kale showed that it could be, overcome by feeding additional iodine to the ewes during gestation (Shand, Allcroft, and Hignett, unpublished data). Analysis of food samples has shown some low iodine values and there appears to be a possibility that thyroid hyperplasia in cattle and sheep may be associated with marginal intakes of iodine as well as with other goitrogens, but much work remains to, be done before the nature of these antithyroid factors is understood.

\section{R eferences}

Allcroft, R. Proc. XV Int. Vet. Congr., Stockholm, Vol. I, Pt. 1, pp. 573. 1953.

Allcroft R. Vet. Rec., Vol. 66, pp. 517. 1954.

Allcroft, R., and Lewis, G. Proc. 7th Int. Grassland Congr., N.Z.

(in press). 1956. pp. 367. 1954

Allcroft, W. M. Vet. J.. Vol. 103, pp. 75. 1947.

Bartlett, S., Brown, B. 'B., Foot, A. S., Rowland, S. J., Allcroft R., and Parr, W. H.' Br. Vet. J., Vol. 110, pp. 3. 1954.

Blaxter, K. L.; and McGill, R. F. Vet. Revs. and Annot., Vol. 2,

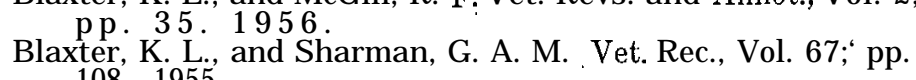
108. 1955 .

Breirem, K., Ender, F., Halse, K., and Slagsvold, L. Acta Agr.

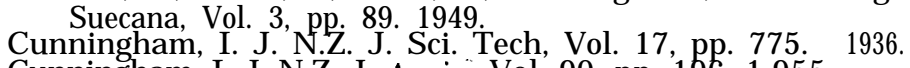

Cunningham, I. J. N.Z. J. A Aric., Vol. 90, pp. 196. 1.955.

Dick, A. T. Aust. Vet. J., Vol. 29, pp. 233. 1953.

Dick, A. T. Aust. Vet. J., Vol. 30, pp. 197. 1954 .

Ferguson, W. S., Lewis, A. H., and Watson, S. J. J. Agr. Sci., Vol. 33 , pp. 44. 1943 .

Green,-H. H. Proc. Roy. Soc Med., Vol. 39, pp. 795. 1946.

Green, H. H. N.V.M.A. PubI. No. 17, pp. 60. 1948.

Jamieson, S., and Harbour, H. E. Vet. Rec., Vol. 59, pp. 102. 1947. 
McElroy, W. D.; and Glass, B., eds. Symposium on Copper Metabolism, pp. 246-270. Johns Hopkins Press, Baltimore, 1950 .

Osborne, A. D., Featherstone, J., and Herdan, G. Vet. Rec., Vol. 66, pp. 409,1954.

Parr, W. H., and Alllcroft, R. Unpublished data. 1956.

Patterson, Jे. B. E. Nature, Vol. 157, pp. 555. 1946.

Shand, A. B.V.A. Publ. No. 23, pp. 58. 1952.

Stewart, J. Guernsey Breeders' J., Vol. 7, pp. 43. 1953.

Stewart, J. Scot. Agric., Vol. 34, pp. 68. 1954.

Stewart, J., Mitchell, R.L., and Stewart, A. B. Emp. J. Exp. Agr., Vol. 14, pp 145. 1946.

Stewart,'J., and Reith, J. W. S. J. Comp. Path., Vol. 66, PP. 1. 1956 .

Swan, J. B., and Jamieson, N. D. N.Z. J. Sci. Tech. .(in IIress). 1956 .

\section{DISCUSSION}

Col. Stafford, Springston: You have just listened to the most lucid speech on the deficiencies. of a number' of elements which are essential to animal life. Now it has been stated that the $\mathrm{nH}$ of a gnod pasture soil.runs between 6.5 and 7 . I can only give you a-little of my own experience; once you get the $\mathrm{pH}$ over 7 , as you do where lime has been put on the land in excess, then you get disastrous results in bone formation, especially in young stock. I must congratulate the speaker on a wonderful paper.

Q. Does Dr Allcroft know of any cases where farmers whose stock have been affected by fluorosis obtained compensation against the particular industrial enterprise which has been the cause of it?

A. Do you mean as a result of a legal claim or do you mean as a result of private negotiations between farmer and i $\mathrm{n} \mathrm{d} \mathrm{u} \mathrm{s} \mathrm{t} \mathrm{r}$ y ?

Q. I am concerned with' the common law right.

A. I do know of cases. Some industries do, by private arrangement, pay compensation to farmers whose land is -adjacent and is severely contaminated.

Q. What is the reason for the incidence of increased grass staggers on pastures fertilised with nitrogen in the early spring?

A. We have no explanation. The increased incidence is not only confined to pastures treated with nitrogen. We have found that by topdressing those. pastures with magnesite it increases the magnesium uptake. of the pasture. The incidence of staggers has been reduced but the incidence cannot be correlated with magnesium content alone, although it was beneficial in the cases we tried.

Q. if crops are grown where there is fluorine contamination do they take up the fluorine and pass the trouble on to somebody else?

A. No, it is not a case of passing it on to somebody else. It has been shown that most plants do not take up fluorine from the soil. There are two exceptions: the tea plant and the camellia which appear to be fluorine collectors. Most 
grasses and root crops do not take: it up from soils. It is mostly a question of. contamination of the surface;, therefore humans get off lightly because we do not eat grass. The inner parts of cabbages and similar. crops are not high in fluorine, only the outer coverings which are removed. Cereal grains are also quite safe.

Q. Is fluorine cumulative? Can small quantities be safely absorbed over long periods or will they produce clinical symptoms? It is sometimes the practice to add fluorine to drinking water.

A Yes, it is cumulative, but if the intake is small animals or cattle do seem to be able to stand considerable amounts without any adverse clinical symptoms at all. If they are continually exposed to it there will be a gradual build-up to three or four thousand parts per million. A concentration of five to six hundred parts per million is normal. It usually takes several years before you get clinical symptoms, then they first show as dental lesions.

Q. Short of clinical symptoms such as swayback are young sheep affected by a deficiency of copper ?

A. I do not think so; we have not associated any loss of condition in young sheep with copper deficiency.

Q. How and when were the magnesites and dolomites applied to the pastures?

4. The magnesite was applied during the spring. The dolomite we have applied on two occasions, one in the autumn and the other in the spring. We found on some plots that just one application in spring-February-March-was quite sufficient.

Q. Were the copper injections to cattle as satisfactory as the application of copper to pasture; also if they are satisfactory are they satisfactory in the case of molybdenum excess as well as simply copper deficiency?

A. We do not usually apply copper to the pastures. It is normally always given as oral supplement or intravenous injection; in sheep always as oral supplement. We have tried an application of copper sulphate to cattle pasture in peaty areas in Scotland and found the effect wore off after six months. Most farmers prefer oral supplements or intravenous injections rather than topdressing of pastures. They are apprehensive about using copper for topdressing pastures because of the toxicity to sheep. Assuming that all our pastures where copper deficiency occurs are used both for cattle and sheep grazing we have not pushed the use of copper sulphate on pastures.

Q. H. van Rensburg: Would water containing more than 30 parts per million of fluorine have detrimental effects on cattle, and how soon? The problem occurs in Tanganyika where we have very high percentages of fluorine in the water and would like to hold young cattle -on the areas for 6-18 months. How long could we safely keep them there?

A. Dr Allcroft : With 30 parts per million in the drinking water you would get clinical effects if you keep them there for 18 months. You could expect to get severe dental 
lesions in the permanent teeth when they came through. If they were then removed and spent the rest of their lives away from it, they might not be so bad, but still there would be harmful effects. Do you have to keep them there that length of time?

H. van Rensburg: We have not kept them in this specific area for any length of time,. but in other areas where there is a high fluorine content in the water it is very noticeable amongst stock -and humans that their teeth are severely affected. Conditions I am referring to would only apply to cattle afterwards drafted to market for slaughter. 